\title{
Sex differences in immune responses
}

\section{Sabra L. Klein ${ }^{1}$ and Katie L. Flanagan²}

Abstract | Males and females differ in their immunological responses to foreign and self-antigens and show distinctions in innate and adaptive immune responses. Certain immunological sex differences are present throughout life, whereas others are only apparent after puberty and before reproductive senescence, suggesting that both genes and hormones are involved. Furthermore, early environmental exposures influence the microbiome and have sex-dependent effects on immune function. Importantly, these sex-based immunological differences contribute to variations in the incidence of autoimmune diseases and malignancies, susceptibility to infectious diseases and responses to vaccines in males and females. Here, we discuss these differences and emphasize that sex is a biological variable that should be considered in immunological studies.

Sex is a biological variable that affects immune responses to both self and foreign antigens (for example, those from fungi, viruses, bacteria, parasites and allergens). The sex of an individual is defined by the differential organization of chromosomes, reproductive organs, and sex steroid levels; it is distinct from gender, which includes behaviours and activities that are determined by society or culture in humans. Male and female differences in immunological responses may be influenced by both sex and gender, with sex contributing to physiologi$\mathrm{cal}$ and anatomical differences that influence exposure, recognition, clearance, and even transmission of microorganisms. By contrast, gender may reflect behaviours that influence exposure to microorganisms, access to healthcare or health-seeking behaviours that affect the course of infection. Although we acknowledge that both sex and gender influence the immune response, the focus of this Review will be on the biological factors that influence immunological differences between the sexes. Despite a growing body of literature illustrating sex-based differences in immune responses, immunology ranks the lowest of ten biological disciplines for reporting the sex of animal or human subjects in published papers, with fewer than $10 \%$ of articles analysing data by sex ${ }^{1}$. The field of sex-based biology is undergoing a revolution, in which research funding agencies and journals have launched policies to promote greater consideration, reporting and analyses of sex and gender in the biomedical sciences in an effort to improve rigour and reproducibility (BOX 1).

It is increasingly important to acknowledge sex differences in immune responses when we consider the marked differences seen between males in females in various diseases. For instance, $80 \%$ of autoimmune disease occurs in females, women with acute HIV infection have $40 \%$ less viral RNA in their blood than men, men show an almost twofold higher risk of death from malignant cancer than women and antibody responses to seasonal influenza vaccines are consistently at least twice as strong in women than men. Generally, adult females mount stronger innate and adaptive immune responses than males. This results in faster clearance of pathogens and greater vaccine efficacy in females than in males but also contributes to their increased susceptibility to inflammatory and autoimmune diseases. In this Review, we explain how these immunological differences between the sexes reflect hormonal, genetic and environmental effects on the immune system that can change throughout life in humans.

\section{Phylogeny of sex differences in immunity}

Mounting immune responses that are necessary for the recognition, response and clearance of pathogens requires metabolic resources that might otherwise be used for other biological processes, such as growth, maintenance of secondary sex characteristics and reproduction. Tradeoffs are likely to exist for life strategies that affect survival and reproduction ${ }^{2}$. Several theories posit that increased pathogen loads and reduced immune function among males are an adverse side effect of positive selection for other traits or characteristics that increase reproductive success and survival ${ }^{2}$. Sex differences in immune responses have evolved in diverse species ranging from insects to lizards, birds and mammals; in all of these species, both innate and adaptive immune responses are typically lower in males than in females (TABLE 1). In Drosophila melanogaster, for example, many of the genes that encode for innate signalling proteins are found on the $\mathrm{X}$ chromosome and show sex-specific induction following fungal or bacterial infection ${ }^{3,4}$. In lizards, the 


\section{Box 1 | A brief history of sex and gender-based research in the US}

The history of excluding females from clinical studies is reflected in the 1977 US Food and Drug Administration (FDA) guidelines advising that women of childbearing potential should be excluded from drug trials. These recommendations resulted in inadequate representation of women in clinical trials for decades. In the early 1990s, the FDA and the National Institutes of Health (NIH) in the US, with advocacy from US Congresswomen, recommended that clinical trials should include female subjects. Although women are now included in clinical trials of drugs, devices and biologics, there remains inadequate analysis of whether outcomes differ between men and women or boys and girls. Of drugs withdrawn from the US market from 1997-2000, the US Government Accountability Office (GAO) reported that 8 out of 10 drugs taken off the market had greater adverse effects in women. In 2015, the US GAO documented that although more women than men currently enrol in NIH-funded clinical research, the $\mathrm{NIH}$ does not ensure that these studies are designed to identify differences between men and women in disease processes and responses to treatment. Preclinical studies in animal models and cell culture systems could help to prevent these costly mistakes but, here too, analysis of potential sex effects has been lacking. Following behind policy changes in Canada and Europe, in 2015 the NIH announced new policies to ensure that sex is considered as a biological variable in preclinical research in an effort to increase rigour and reproducibility. response elements (AREs) and oestrogen response elements (EREs) are present in the promoters of several innate immunity genes, suggesting that sex steroids may directly cause dimorphic innate immune responses ${ }^{12}$.

The production of cytokines and chemokines by innate immune cells also differs between the sexes. Activation of TLR9 with viral or synthetic ligands in PBMCs from human males results in greater interleukin-10 (IL-10) production compared with PBMCs from females, which is positively correlated with androgen concentration in males ${ }^{13}$. PBMCs from human males produce more TNF than PBMCs from females following lipopolysaccharide (LPS) stimulation ${ }^{14,15}$. Neutrophils from human males express higher levels of TLR4 and produce more TNF than female neutrophils both constitutively and following activation with LPS ${ }^{16}$. Peritoneal macrophages from male mice express higher levels of TLR4 and produce more CXC-chemokine ligand 10 (CXCL10) following LPS stimulation than macrophages from females ${ }^{17}$. Peritoneal macrophages isolated from female rodents produce higher levels of anti-inflammatory prostanoids than male-derived cells following LPS treatment ${ }^{17}$. Because TLR4 expression is greater on immune cells from males than females, stimulation with LPS results in greater pro-inflammatory cytokine production by male immune cells, which can be reversed by removal of androgens in male rodents ${ }^{18}$. By contrast, higher expression of TLR7 in immune cells from females compared with males seems to cause greater cytokine production by female immune cells and is regulated by sex chromosome expression. The sex differential expression of PRRs is crucial for interpreting sex-specific activity of innate immune cells following stimulation.

The number and activity of cells associated with innate immunity differ between the sexes. Males have higher natural killer (NK) cell frequencies than females ${ }^{19}$. The phagocytic activity of neutrophils and macrophages is higher in females than males ${ }^{20}$. Antigen-presenting cells (APCs) from females are more efficient at presenting peptides than APCs from males ${ }^{21}$. Finally, sex differences are also seen in innate lymphoid cells (ILCs), which are innate-like lymphocytes that regulate an array of tissue immune responses through the production of effector cytokines. Dysregulation of ILCs is linked to the development of autoimmune diseases, and females reportedly have reduced numbers of type 2 ILCs, which is hypothesized to contribute to their increased susceptibility to demyelination in a mouse model of multiple sclerosis ${ }^{22}$.

Sex differences in adaptive immunity in mammals Sex influences multiple aspects of adaptive immunity (FIG. 1; TABLE 2). The thymus plays a pivotal part in the development of the adaptive immune system by producing the peripheral $\mathrm{T}$ cell pool. Early in life, male rats have larger thymuses, greater thymocyte counts and differential distribution of thymocyte subsets compared with female rats ${ }^{23,24}$.

Among adult humans, sex differences in lymphocyte subsets - including B cells, $\mathrm{CD} 4^{+} \mathrm{T}$ cells and $\mathrm{CD}^{+} \mathrm{T}$ cells - are described for multiple ethnic groups 
Table 1 | Sex differences in immune responses in different species

\begin{tabular}{|c|c|c|c|}
\hline Common name & Species & Immune component & Sex difference \\
\hline Sea urchin & $\begin{array}{l}\text { Paracentrotus } \\
\text { lividus }\end{array}$ & $\begin{array}{l}\text { Number of immunocytes, } \\
\text { cytotoxic activity, } \\
\text { phagocytosis and haemolysis }\end{array}$ & $\begin{array}{l}\text { Greater in females } \\
\text { than in males }\end{array}$ \\
\hline Fruit fly & $\begin{array}{l}\text { Drosophila } \\
\text { melanogaster }\end{array}$ & $\begin{array}{l}\text { Activation of Toll and } \\
\text { immune deficiency signalling }\end{array}$ & $\begin{array}{l}\text { Greater in females } \\
\text { than in males }\end{array}$ \\
\hline Scorpionfly & $\begin{array}{l}\text { Panorpa } \\
\text { vulgaris }\end{array}$ & $\begin{array}{l}\text { Haemolysis and } \\
\text { phagocytosis }\end{array}$ & $\begin{array}{l}\text { Greater in females } \\
\text { than in males }\end{array}$ \\
\hline Wall lizard & $\begin{array}{l}\text { Podarcis } \\
\text { muralis }\end{array}$ & Macrophage phagocytosis & $\begin{array}{l}\text { Greater in females } \\
\text { than in males }\end{array}$ \\
\hline Eurasian kestrels & $\begin{array}{l}\text { Falco } \\
\text { tinnunculus }\end{array}$ & Hypersensitivity responses & $\begin{array}{l}\text { Greater in females } \\
\text { than in males }\end{array}$ \\
\hline Great tit & Parus major & Hypersensitivity responses & $\begin{array}{l}\text { Greater in females } \\
\text { than in males }\end{array}$ \\
\hline House mouse & Mus musculus & $\begin{array}{l}\text { Pro-inflammatory cytokine } \\
\text { responses, T cell proliferation } \\
\text { and antibody responses }\end{array}$ & $\begin{array}{l}\text { Greater in females } \\
\text { than in males }\end{array}$ \\
\hline Rhesus macaque & $\begin{array}{l}\text { Macaca } \\
\text { mulatta }\end{array}$ & $\begin{array}{l}\text { Pro-inflammatory cytokine } \\
\text { responses and antibody } \\
\text { responses }\end{array}$ & $\begin{array}{l}\text { Greater in females } \\
\text { than in males }\end{array}$ \\
\hline Human & Homo sapiens & $\begin{array}{l}\text { Type I interferon activity, } \\
\text { T cell numbers and antibody } \\
\text { responses }\end{array}$ & $\begin{array}{l}\text { Greater in females } \\
\text { than in males }\end{array}$ \\
\hline
\end{tabular}

including Europeans, Asians, and Africans. Females (both children and adults) have higher $\mathrm{CD} 4^{+} \mathrm{T}$ cell counts and higher CD4/CD8 ratios than age-matched males ${ }^{19,25-27}$; whereas males have higher $\mathrm{CD}^{+} \mathrm{T}$ cell frequencies $^{25-27}$. Following in vitro stimulation of PBMCs, women have higher numbers of activated $\mathrm{CD} 4^{+} \mathrm{T}$ cells and $\mathrm{CD}^{+} \mathrm{T}$ cells and proliferating $\mathrm{T}$ cells in peripheral blood compared to men $^{19,28}$. Transcriptional analyses indicate greater cytotoxic $\mathrm{T}$ cell activity in adult females, with PMA-ionomycin-stimulated T cells from women upregulating more antiviral genes (such as IFNG, RIGI, SPINK5, OAS1 and IFI6) and pro-inflammatory genes (for example, IL12RB2, IL1F5, CXC3CL1, CXCL2 and IL16) compared with T cells isolated from men ${ }^{29}$. Notably, half of the activated genes in female T cells have EREs in their promoters ${ }^{29}$.

The activity and distribution of $\mathrm{CD} 4^{+} \mathrm{T}$ cell subsets differ between the sexes. Adult female mice produce higher levels of $\mathrm{T}$ helper $1\left(\mathrm{~T}_{\mathrm{H}} 1\right)$-type cytokines (for example, IFN $\gamma$ ) than males, at least following parasitic infections, such as Leishmania major and Plasmodium chabaudi, in which females are better protected ${ }^{30}$. Polyclonal activation of human PBMCs with the mitogen phytohaemagglutinin (PHA) results in higher production of $\mathrm{T}_{\mathrm{H}}$ 2-type cytokines, including IL-4 and IL-10 in female PBMCs than in male PBMCs ${ }^{31}$. The $\mathrm{T}_{\mathrm{H}} 1-\mathrm{T}_{\mathrm{H}} 2$ dichotomy in males and females may not always hold true in humans. Naive $\mathrm{CD} 4^{+} \mathrm{T}$ cells from human females preferentially produce IFN $\gamma$ upon stimulation, whereas naive $\mathrm{T}$ cells from males produce more IL-17 (REF. 32). Expression of IL-17A is higher in males ${ }^{29}$ or females ${ }^{28}$, depending on the stimulation and purity of the T cell population. Mouse studies investigating sex differences in regulatory $\mathrm{T}\left(\mathrm{T}_{\mathrm{reg}}\right)$ cells describe contradictory results regarding organ-specific $\mathrm{T}_{\text {reg }}$ cell frequencies in various diseases, whereas human studies suggest there are higher numbers of $\mathrm{T}_{\text {reg }}$ cells in healthy adult males compared with females ${ }^{33}$.

Regardless of age, females tend to show greater antibody responses than males, higher basal immunoglobulin levels and higher B cell numbers ${ }^{19,34,35}$. Global analysis of B cell gene-expression signatures reveal that the majority of genes differentially expressed between the sexes are significantly upregulated in B cells from females compared with males ${ }^{36}$.

\section{Genetic mediators}

Sex chromosomes. Many genes on the X chromosome regulate immune function and play an important role in modulating sex differences in the development of immune-related diseases ${ }^{37}$ (BOX 2). These genes code for proteins ranging from PRRs (for example, TLR7 and $T L R 8$ ) to cytokine receptors (for example, IL2RG and IL13RA2) and transcriptional factors (for example, FOXP3). The Y chromosome also contains numerous regulatory response genes, and Y chromosome polymorphisms affect sex-dependent susceptibility to viral infection $^{38}$.

The SRY gene on the Y chromosome causes testes formation and testosterone synthesis, leading to male phenotypic development, whereas the absence of SRY expression results in ovaries and female-typic development. The 'four core genotypes' (FCG) mouse model was developed to investigate the impact of sex chromosomes (XX versus XY) and gonadal type (testes versus ovaries) on phenotypes. Deletion of Sry from the Y chromosome results in XY minus $\left(\mathrm{XY}^{-}\right)$FCG mice that are gonadal females (that is, with ovaries). Insertion of the Sry transgene onto an autosome in XX or XY- FCG mice (XXSry and $\mathrm{XY}^{-} S r y$ ) results in gonadal males (that is, with testes). Depletion of gonadal steroids by gonadectomy of FCG mice unmasks effects of sex chromosome complement on multiple functions, including susceptibility to autoimmune disease and viral infection ${ }^{39,40}$. In experimental autoimmune encephalitis (EAE) and lupus, for example, the presence of the XX sex chromosome complement worsens disease progression, relative to that in the XY mice, and results in decreased production of IL-4, IL-5 and IL-13, but increased IL-13Ra2 expression on DCs ${ }^{39}$.

Klinefelter and Turner syndromes are two inherited disorders that further exemplify the effects of the $\mathrm{X}$ chromosome on immunity. Klinefelter syndrome occurs when males have an extra X chromosome, resulting in low testosterone, increased gonadotrophins and elevated oestrogen concentrations. Immunologically, men with Klinefelter syndrome respond more like females, with higher immunoglobulin concentrations, $\mathrm{CD}^{+} \mathrm{T}$ cell numbers, CD4/CD8 $\mathrm{T}$ cell ratios and $\mathrm{B}$ cell numbers than XY male controls ${ }^{41}$. The immunological effects of Klinefelter syndrome are reversed by testosterone therapy ${ }^{41}$, illustrating that both sex chromosomes and sex steroids regulate immune responses. By contrast, women with Turner syndrome (that is, who have only one X chromosome (X0) or have major X chromosome deletions ${ }^{42}$ ) have lower IgG and IgM levels and 
Table 2 | Sex differences in innate and adaptive immune responses in adults*

\begin{tabular}{|c|c|c|}
\hline $\begin{array}{l}\text { Immune } \\
\text { component }\end{array}$ & Characteristic & Sex difference \\
\hline \multicolumn{3}{|c|}{ Sex differences in the innate immune system } \\
\hline \multirow[t]{3}{*}{ TLR pathways } & TLR pathway gene expression & Higher in females \\
\hline & TLR7 expression & Higher in females \\
\hline & $\begin{array}{l}\text { IL-10 production by TLR9-stimulated } \\
\text { PBMCs }\end{array}$ & Higher in males \\
\hline APCs & APC efficiency & Higher in females \\
\hline \multirow[t]{2}{*}{ Dendritic cells } & TLR7 activity & Higher in females \\
\hline & Type 1 interferon activity & Higher in females \\
\hline \multirow[t]{5}{*}{ Macrophages } & TLR4 expression & Higher in males \\
\hline & Activation & Higher in females \\
\hline & Phagocytic capacity & Higher in females \\
\hline & Pro-inflammatory cytokine production & Higher in males \\
\hline & IL-10 production & Higher in females \\
\hline \multirow[t]{2}{*}{ Neutrophils } & Phagocytic capacity & Higher in females \\
\hline & TLR expression & Higher in males \\
\hline NK cells & NK cell numbers & Higher in males \\
\hline \multicolumn{3}{|c|}{ Sex differences in the adaptive immune system } \\
\hline Thymus & Size of thymus & Larger in males \\
\hline \multirow[t]{8}{*}{ T cells } & $\mathrm{CD} 4^{+} \mathrm{T}$ cell counts & Higher in females \\
\hline & CD4/CD8 T cell ratio & Higher in females \\
\hline & $\mathrm{CD} 8^{+} \mathrm{T}$ cell counts & Higher in males \\
\hline & Number of activated T cells & Higher in females \\
\hline & T cell proliferation & Greater in females \\
\hline & Cytotoxic T cells & $\begin{array}{l}\text { Increased cytotoxic } \\
\text { activity in females }\end{array}$ \\
\hline & $T_{H} 1$ versus $T_{H} 2$ cell bias & $\begin{array}{l}T_{H} 2 \text { cell bias in females, } \\
T_{H} 1 \text { cell bias in males }\end{array}$ \\
\hline & $\mathrm{T}_{\text {reg }}$ cell numbers & Increased in males \\
\hline B cells & B cell numbers & Increased in females \\
\hline Immunoglobulins & Antibody production & Higher in females \\
\hline
\end{tabular}

APC, antigen-presenting cell; IL, interleukin; NK, natural killer; PBMCs, peripheral blood mononuclear cells; $T_{H}, T$ helper; TLR, Toll-like receptor; $T_{\text {reg, }}$, regulatory T. *Based on data from humans and rodents and primary cell cultures.

lower $\mathrm{T}$ cell and B cell levels compared to XX females ${ }^{43}$. Both patients with Klinefelter syndrome and patients with Turner syndrome show increased development of autoimmune disease, pointing to a major role for the X chromosome in influencing susceptibility to autoimmunity ${ }^{42}$.

MicroRNAs and long non-coding RNA. Much of the mammalian genome encodes for transcripts that are not translated into proteins, including microRNAs (miRNAs) and long non-coding RNAs (lncRNAs). Despite the fact that male and female invertebrates and higher organisms differentially express miRNAs, few studies have addressed the role of miRNAs in sex differences in diseases ${ }^{44}$. The $\mathrm{X}$ chromosome contains $10 \%$ of the $~ 800$ miRNAs in the human genome, whereas the $\mathrm{Y}$ chromosome only contains 2 miRNAs ${ }^{45}$. MiRNAs
- including miRNA-18 and miRNA-19, which are encoded on the $\mathrm{X}$ chromosome - play a role in sex differences in immune responses ${ }^{46}$. MicroRNA expression can be under sex hormone control ${ }^{47}$. The high density of miRNAs on the $\mathrm{X}$ chromosome means that females may express more owing to incomplete $\mathrm{X}$ inactivation (BOX 2), further contributing to sex differences in susceptibility to certain diseases.

The lncRNAs play a vital role in the regulation of multiple immunological processes, including transcriptional regulation of innate and adaptive immunity ${ }^{48}$ and as a catalyst of $\mathrm{X}$ inactivation in a manner that has been shown to be sex-differential ${ }^{49}$.

Genetic polymorphisms. Polymorphisms or variability in sex chromosome and autosomal genes encoding immunological proteins can have sex-differential effects on immunity. For example, sex-based differences in HLA alleles and genes that encode for IL-4, IL-10 and the IL-12 receptor, have each been associated with differential antibody responses to vaccines against measles, mumps, hepatitis A, tetanus and diphtheria in children and adults $^{11}$. Whether sex-based differences in the expression of gene variants are caused by differential selection pressures acting on each sex, hormone-dependent effects, or epigenetic mechanisms remain to be determined but, because these differences are apparent early in life and remain over the life course, genetic as opposed to hormonal mechanisms are likely to be involved ${ }^{50}$.

\section{Hormonal mediators}

Oestradiol. Levels of oestrogen, for example, $17 \beta$-oestradiol (E2), are variable during the menstrual cycle, high during pregnancy and low after menopause in females. ERs are expressed in various lymphoid tissue cells, in lymphocytes, macrophages, and DCs. The two ER subtypes for classical oestrogen signalling, ERa and $E R \beta$, exhibit differential expression among immune cell subsets; ERa is highly expressed in T cells and ER $\beta$ is upregulated in $\mathrm{B}$ cell $\mathrm{s}^{51}$. Non-classical ER signalling also occurs in immune cells, enabling protein-protein interactions between ERs and ERE-independent transcription factors, including NF- $\mathrm{KB}$, specific protein 1 (SP1) and activator protein 1 (AP-1) $)^{52}$. Differential effects of oestrogens on immune function reflect not only oestrogen concentration but also the density, distribution and type of ERs in immune cells.

E2 affects many aspects of innate immunity (TABLE 3), including the functional activity of innate immune cells that influence downstream adaptive immune responses. Treatment of either humans or mice with E2 increases neutrophil numbers in the blood and lungs, respectively ${ }^{5,54}$. Exposure of NK cells to E2 in vitro enhances production of IFN $\gamma$ and overall cytotoxicity ${ }^{55}$, but also downregulates expression of NK cell surface activation markers and FAS ligand (FASL), and reduces their secretion of granzyme B in mice ${ }^{56}$. E2 has bipotential effects on monocytes and macrophages derived from humans, with low doses enhancing the production of proinflammatory cytokines (such as IL-1, IL-6 and TNF) and high concentrations reducing their production of 


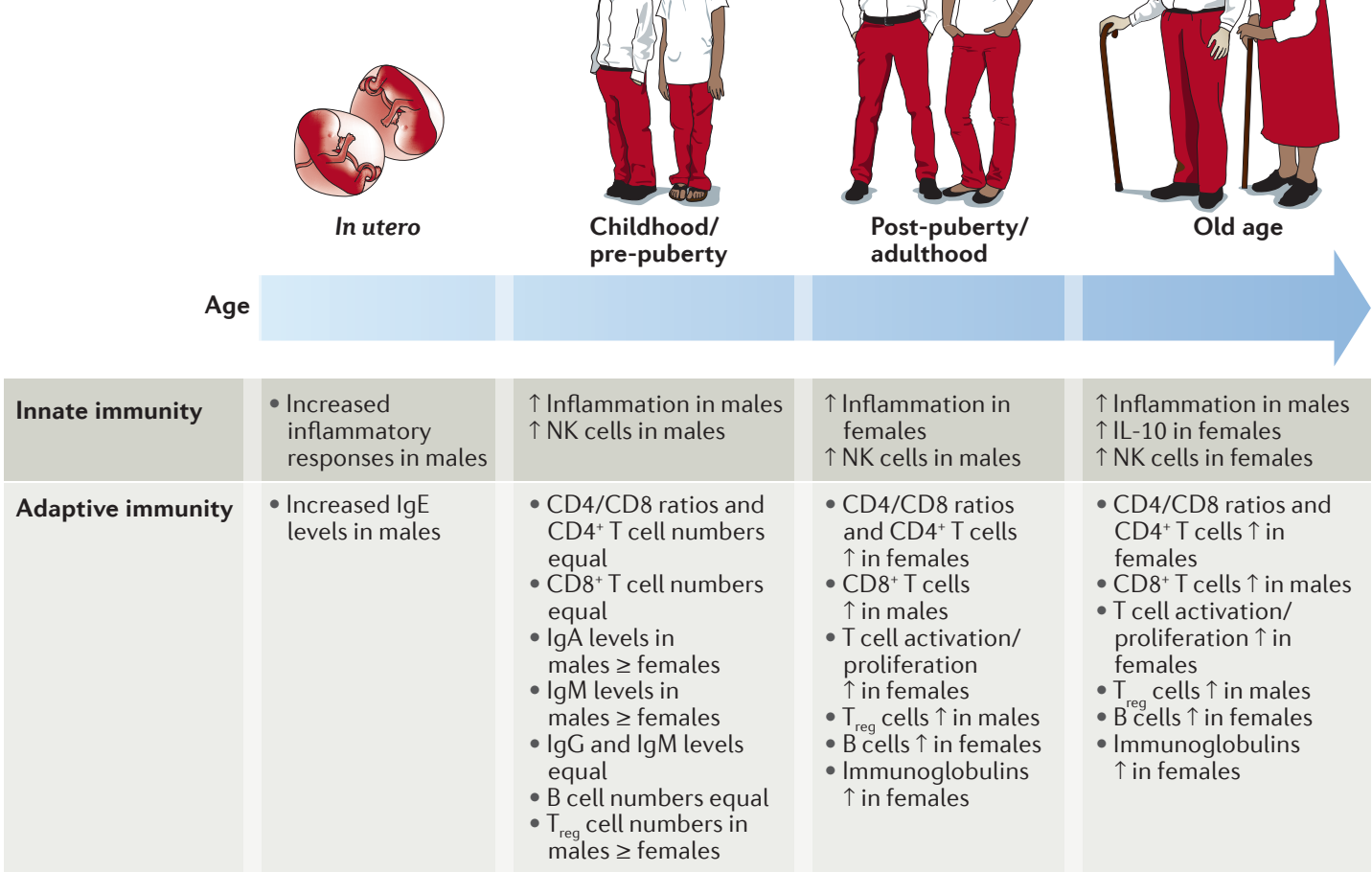

Figure 1 | Changes in immune responses in human males and females over the life course. Multiple immunological factors vary between the sexes throughout the course of life. For certain factors (for example, pro-inflammatory responses), the sex differences change at puberty and then wane in later life suggesting hormonal effects. For other factors the sex difference remains constant from birth to old age (for example, higher numbers of $C D 4^{+} \mathrm{T}$ cells and CD4/CD8 T cell ratios in females). The paucity of studies in this area is notable, particularly in utero sex differences in which results are conflicting. IL-10, interleukin-10; NK, natural killer; $\mathrm{T}_{\text {reg }}$, regulatory $\mathrm{T}$.

these cytokines ${ }^{57}$. E2 also enhances the expression of PRRs, including TLR4, on the surface of peritoneal macrophages in rodents ${ }^{58}$. In vitro E2 exposure facilitates the differentiation of bone marrow precursor cells into functional CD11 $\mathrm{c}^{+} \mathrm{DCs}^{59}$ and increases the synthesis of CXCL8 and CC-chemokine ligand 2 (CCL2) by immature DCs in mice ${ }^{60}$. Treatment of ovariectomized mice with physiological doses of $\mathrm{E} 2$ increases production of pro-inflammatory cytokines by CD11 $\mathrm{c}^{+} \mathrm{DCs}^{61,62}$. E2 acts primarily through $\mathrm{ER} \alpha$, not $\mathrm{ER} \beta$, to regulate $\mathrm{DC}$ differentiation in mice $^{59}$. In response to granulocytemacrophage colony-stimulating factor (GM-CSF) in human monocyte cell systems, E2 promotes differentiation of monocytes into inflammatory DCs, which show increased production of IFNa and pro-inflammatory cytokines, increased TLR7 and TLR9 signalling, and greater internalization and presentation of antigen to naive $\mathrm{T}$ cells ${ }^{63}$. This is most likely to contribute to the greater type I IFN activity seen in immune cells from females than in males.

E2 enhances both cell-mediated and humoral immune responses (TABLE 3). Generally, low E2 concentrations promote $\mathrm{T}_{\mathrm{H}} 1$-type responses and cell-mediated immunity, whereas high E2 concentrations augment $\mathrm{T}_{\mathrm{H}}$ 2-type responses and humoral immunity in diverse species and cell culture systems ${ }^{64}$. Binding of E2 to ERs increases Ifng transcription via EREs in the promoter region of the Ifng gene ${ }^{65}$. Low dose E2 also upregulates mitogen activated protein kinase (MAPK), T-bet, and select miRNAs to increase production of IFN $\gamma$ by T cells, an effect reversed by the ER antagonist ICI 182,780 in murine studies ${ }^{66-68}$. E2 regulates pro-inflammatory responses that are transcriptionally mediated by NF- $\kappa B$ through a negative feedback and/or transrepressive interaction with $\mathrm{NF}-\kappa \mathrm{B}^{64}$.

Exogenous E2 enhances the expansion of $\mathrm{T}_{\text {reg }}$ cell populations in mice and healthy women and, in vitro, $\mathrm{E} 2$ increases the number of $\mathrm{T}_{\text {reg }}$ cells generated from $\mathrm{PBMCs}^{69,70}$. Treatment of mice with high doses of E2 decreases IL-17 production by $\mathrm{T}_{\mathrm{H}} 17$ cells $^{71}$, whereas ovariectomy of female mice increases $\mathrm{T}_{\mathrm{H}} 17$ cell numbers and IL-17 production ${ }^{72}$. E2 at physiological concentrations also stimulates humoral responses to infection ${ }^{73}$. Numbers of antibody-secreting cells and antibody levels are highest before ovulation in females ${ }^{73}$. Oestrogen also induces somatic hypermutation and class switch recombination in B cells via the upregulation of activation-induced deaminase ${ }^{74}$.

Progesterone. Progesterone (P4) is produced by the corpus luteum during the menstrual cycle and at high levels by the placenta during pregnancy. P4 signals through 


\section{Box $2 \mid$ Sex chromosomes and $\mathrm{X}$ inactivation}

In humans, sex chromosomes are heterologous in males $(X Y)$ and homologous in females (XX). The human $Y$ chromosome contains approximately 100 genes, including $S R Y$, which encodes for the testis determining factor, and regulatory genes that may be important for immune responses in autoimmune and infectious diseases ${ }^{38,144}$. The human $\mathrm{X}$ chromosome contains over 1,100 annotated genes, representing approximately $5 \%$ of the human genome, and includes a significant number of immune related genes, such as interleukin 2 (IL-2) receptor- $\gamma$ chain, IL-3 receptor- $\alpha$ chain, IL-13 receptor- $\alpha$ chains, Toll-like receptor 7 (TLR7), TLR8, GATA1, IL-1 receptor-associated kinase 1 (IRAK1), CD40 ligand and FOXP3 (REF. 145). Several crucial transcriptional and translational control effectors, that function downstream of activated cytokine receptors, are encoded on the $\mathrm{X}$ chromosome. The implications are that $\mathrm{X}$-linked genes are determinants of sex differential immune responses. For genes on the $\mathrm{X}$ chromosome, outside of the pseudoautosomal regions, one copy has to be silenced to ensure only a single copy functions in each sex. Inactivation is initiated by the X-inactive specific transcript (XIST) gene. Approximately $15 \%$ of $X$ genes in humans and $3 \%$ in mice escape $X$ inactivation and are found in higher copy number in females than males. For $X$-linked genes that are inactivated in females, the random process of inactivation of copies derived from the maternal or paternal $X$ chromosome results in a mosaic in females, but not in males. Genomic imprinting is an epigenetic mechanism that is responsible for an imbalance in expression of maternal and paternal inherited genes according to the parent-of-origin. It varies in different tissues and at different developmental stages. In mice, the expression levels of certain imprinted genes vary between the $\operatorname{sexes}^{146}$. In addition to sex differences in transcription, there are also sex differences in post-transcriptional mechanisms. synthesis of TNF, iNOS and NO by macrophages ${ }^{84}$. Testosterone and DHT increase IL-10 and transforming growth factor- $\beta$ (TGF $\beta$ ) synthesis, causing increased anti-inflammatory responses via androgen receptor signalling ${ }^{84,85}$. Androgens also suppress pro-inflammatory responses by reducing extracellular signal-regulated kinases and leukotriene formation in neutrophils ${ }^{86}$.

Men with androgen deficiencies have higher concentrations of inflammatory cytokines (for example, IL-1 $\beta$, IL-2 and TNF), antibody titers and CD4/CD8 T cell ratios than men with normal testosterone levels ${ }^{87-90}$. Men treated with a gonadotropin-releasing hormone antagonist, which significantly reduces testosterone levels, have lower peripheral blood $\mathrm{T}_{\text {reg }}$ cell counts and higher NK cell counts compared with placebo-treated men or men treated with both the gonadotropin-releasing hormone antagonist and exogenous testosterone ${ }^{91}$. Castrated male mice have higher numbers of $\mathrm{CD}^{+}$and $\mathrm{CD}^{+} \mathrm{T}$ cells $^{92}$ and higher numbers of macrophages and antigen-specific $\mathrm{CD}^{+} \mathrm{T}$ cells following viral infection than gonadally intact males ${ }^{93}$. Treatment of female mice with testosterone inhibits secretion of IFN $\gamma$ by natural killer T cells ${ }^{94}$.

The immunosuppressive effects of androgens may reflect the inhibitory effects of androgen receptor signalling on transcriptional factors for pro-inflammatory and antiviral cytokines ${ }^{95}$. Androgens also enhance the expression of peroxisome proliferator-activated receptor- $\alpha$ (PPAR $\alpha$ ) in T cells by engaging AREs in the promoter of the PPARa gene, which repress the activity of NF- $\kappa$ B and JUN to control inflammation ${ }^{96}$. Taken together, these studies illustrate that sex steroids are potent regulators of immune responses.

\section{Environmental mediators}

Although genes and hormones are the most well characterized mediators of sex differences in immune responses, environmental factors can also modulate the functioning of the immune system differentially between males and females. macrophages, and reduces production of inducible nitric oxide synthase (iNOS) and nitric oxide $(\mathrm{NO})^{78}$. TLR and the NF- $\kappa \mathrm{B}$ pathways can also be antagonized by the action of P4 (REFS 76,79). Treatment of human NK cells with $\mathrm{P} 4$ reduces activation and production of IFN $\gamma$ via caspase-dependent apopto$\mathrm{sis}^{80}$. Progesterone can promote skewing of $\mathrm{CD} 4^{+} \mathrm{T}$ cell responses from $\mathrm{T}_{\mathrm{H}} 1$-type towards $\mathrm{T}_{\mathrm{H}} 2$-type responses, as characterized by increased IL-4, IL-5, and IL-10 production $^{81}$. When cord blood cells are treated with P4, the percentage of FOXP3 ${ }^{+} \mathrm{T}_{\text {reg }}$ cells increases, while $\mathrm{T}_{\mathrm{H}} 17$ cell frequencies decline ${ }^{82}$. Whether $\mathrm{P} 4$ contributes directly to male-female differences in the skewing of $\mathrm{CD} 4^{+} \mathrm{T}$ cell responses requires consideration.

Androgens. Androgens, including dihydrotestosterone (DHT) and testosterone, occur in higher concentrations in post-pubertal men than women, and they generally suppress immune cell activity ${ }^{30}$ (TABLE 3). Exposure to testosterone in vivo reduces NK cell activity in mice ${ }^{83}$. Surface expression of TLR4 on macrophages is reduced by exposure to testosterone both in vitro and in vivo, driving increased susceptibility to endotoxic shock following gonadectomy of male mice ${ }^{18}$. Testosterone reduces the
Nutrition. The nutritional environment of the fetus can have differential effects depending on its sex. Maternal micronutrient supplementation during pregnancy in a Gambian placebo-controlled study reported sex differences in CpG methylation of genes involved in immunity and defence against infection (for example, genes encoding CD4, defensins and genes associated with IFN signalling), and female fetuses were most affected in the supplemented group whereas males were most affected in the non-supplemented group ${ }^{97}$. The study demonstrates that sex-differential developmental trajectories commence in utero and persist to 9 months of age, indicating long-term epigenetic reprogramming in relation to nutrition during pregnancy. A high-fat diet also enhances, whereas prenatal exposure to famine reduces, placental gene expression and DNA hypomethylation to a greater extent in female than in male fetuses ${ }^{98}$. Several studies also suggest that the immunomodulatory effects of breast milk may benefit infant females more than males, with breastfeeding reducing the risk of neonatal respiratory tract infection in female but not male infants ${ }^{99}$. 
Table 3 | Effects of sex steroid hormones on innate and adaptive immunity

\begin{tabular}{|c|c|c|c|}
\hline \multirow{2}{*}{$\begin{array}{l}\text { Immune } \\
\text { component }\end{array}$} & \multicolumn{3}{|c|}{ Effect of sex hormones* } \\
\hline & Oestradiol & Progesterone & Androgens \\
\hline TLRs & 个TLR4, TLR7 and TLR9 & $\downarrow T L R 3$ and TLR7 & $\downarrow T L R 4$ \\
\hline Macrophages & 个TLR4 & $\begin{array}{l}\downarrow \text { iNOS and NO } \\
\uparrow F I Z Z 1 \text { and YM1 }\end{array}$ & $\begin{array}{l}\downarrow \text { iNOS/NO } \\
\downarrow \text { TNF }\end{array}$ \\
\hline$N F-\kappa B$ & $\downarrow$ Activity & $\downarrow$ Activity & $\downarrow$ Activity \\
\hline DCs & $\begin{array}{l}\uparrow \text { Activation } \\
\uparrow T L R 7 \text { and TLR9 } \\
\uparrow C C L 2 \\
\downarrow C X C L 10 \\
\downarrow I F N a\end{array}$ & $\begin{array}{l}\downarrow C D 40, \text { CD80, CD86 } \\
\text { and } \uparrow C D 11 \mathrm{c} \\
\uparrow I \mathrm{~L}-18 \text { and IL-10 }\end{array}$ & ND \\
\hline Neutrophils & $\begin{array}{l}\uparrow \text { Numbers } \\
\uparrow \text { Degranulation } \\
\uparrow E l a s t a s e \text { release }\end{array}$ & ND & $\begin{array}{l}\uparrow \text { Numbers } \\
\downarrow \text { Kinases and } \\
\text { leukotriene } \\
\text { formation }\end{array}$ \\
\hline NK cells & $\begin{array}{l}\uparrow I F N \gamma \\
\uparrow G r a n z y m e ~ B \\
\downarrow F A S L\end{array}$ & $\begin{array}{l}\uparrow \text { Numbers } \\
\uparrow \text { Apoptosis (caspase } \\
\text { dependent) }\end{array}$ & ND \\
\hline Eosinophils & $\begin{array}{l}\downarrow \text { Numbers } \\
\downarrow \text { Mobilization }\end{array}$ & $\uparrow$ Numbers & ND \\
\hline $\begin{array}{l}\text { Inflammatory } \\
\text { cytokines }\end{array}$ & $\begin{array}{l}\text { Low oestrogen: } \\
\uparrow I L-1 \beta, \text { IL-6, andTNF } \\
\text { High oestrogen: } \\
\downarrow L-1 \beta, \text { IL- } 6 \text { and TNF }\end{array}$ & $\begin{array}{l}\downarrow T N F \text { and IFN } \gamma \\
\uparrow I L-6\end{array}$ & $\begin{array}{l}\uparrow I L-1 \beta \text { and IL-2 } \\
\downarrow T N F\end{array}$ \\
\hline $\begin{array}{l}\text { Suppressive } \\
\text { cytokines }\end{array}$ & 个IL-4, IL-10 and TGF $\beta$ & 个IL-4, IL-5 and TGF $\beta$ & $\uparrow I L-10$ and TGF $\beta$ \\
\hline Chemokines & $\begin{array}{l}\downarrow C C L 2 \\
\uparrow C X C L 1\end{array}$ & $\downarrow C X C L 2$ & $\downarrow C C L 3$ \\
\hline $\mathrm{T}_{\mathrm{H}} 1$ cells & $\begin{array}{l}\text { Low oestradiol: } \\
\uparrow \text { Activity }\end{array}$ & $\downarrow$ Activity & $\downarrow \mathrm{IFN} \gamma$ \\
\hline $\mathrm{T}_{\mathrm{H}} 2$ cells & $\begin{array}{l}\text { High oestradiol: } \\
\uparrow \text { Activity }\end{array}$ & $\uparrow$ Activity & $\begin{array}{l}\downarrow I L-4 \text { and IL-5 } \\
\downarrow \text { GATA3 }\end{array}$ \\
\hline $\mathrm{T}_{\mathrm{H}} 17$ cells & $\begin{array}{l}\downarrow \text { Numbers } \\
\downarrow \text { IL-17 }\end{array}$ & $\downarrow$ Percentages & 个IL-17 \\
\hline $\mathrm{T}_{\text {reg }}$ cells & $\uparrow$ Numbers & $\uparrow$ Percentages & $\uparrow$ Numbers \\
\hline $\mathrm{CD} 8+\mathrm{T}$ cells & $\uparrow$ Response & $\downarrow$ Response & $\begin{array}{l}\downarrow \text { Numbers } \\
\downarrow \text { Activity }\end{array}$ \\
\hline B cells & $\uparrow \lg G$ and $\lg M$ & $\downarrow C D 80$ and $C D 86$ & ND \\
\hline $\begin{array}{l}\text { Antibody } \\
\text { responses }\end{array}$ & $\uparrow$ Response & $\begin{array}{l}\uparrow \text { Total antibody } \\
\downarrow \text { Autoantibodies }\end{array}$ & $\downarrow$ Response \\
\hline
\end{tabular}

CCL, CC-chemokine ligand; CXCL, CXC-chemokine ligand; DCs, dendritic cells; FASL, FAS ligand; IFN, interferon; IL, interleukin; iNOS, inducible nitric oxide synthase; ND, not defined; NF- $\mathrm{kB}$, nuclear factor- $\mathrm{kB}$; NK, natural killer; NO, nitric oxide; TGF $\beta$, transforming growth factor- $\beta$;

$T_{H}$, helper; TLR, Toll-like receptor; $T N F$, tumour necrosis factor; $\mathrm{T}_{\text {reg, }}$, regulatory $\mathrm{T}$. ${ }^{*}$ There is growing evidence that immune cells have sex hormone receptors and can respond directly to the presence, absence or changes in the concentrations of sex steroid hormones. Androgens (including testosterone), oestrogens (including $17 \beta$-oestradiol), and progesterone can have distinct and overlapping effects on the recruitment and activity of diverse immune cell populations in humans, rodents and primary cell culture systems. Generally, testosterone and progesterone are anti-inflammatory, suppressing several of the immune responses necessary for inflammation. Oestradiol has bipotential effects: low concentrations of oestradiol (for example, during the follicular stage of the reproductive cycle) can be pro-inflammatory, whereas high concentrations of oestradiol (for example, during the luteal phase of the reproductive cycle or during pregnancy) can be anti-inflammatory.
There is accumulating evidence that micronutrients act differently in males and females. Perinatal and postnatal vitamin $B$, vitamin $C$ and vitamin E supplements are associated with a $32 \%$ reduction in mortality among females but not males in a randomized placebocontrolled trial of Tanzanian mothers infected with HIV $^{100}$. Studies conducted in African and Asian infants suggest that females may benefit more than males from maternal micronutrient supplements ${ }^{101,102}$. Vitamin A supplementation (VAS), given with measles vaccination to children between 6 and 23 months of age, have sex differential immunomodulatory effects compared to a placebo, including decreased leukocyte subsets in males, and increased numbers of leukocytes and IFN $\gamma$ production by ex vivo stimulated cells from females ${ }^{103}$.

Microbiota. A perturbed microbiome - referred to as dysbiosis - contributes to various disease processes including inflammation and diabetes. Sex influences the host microbiome outside of the reproductive tract, which probably involves sex steroid hormones ${ }^{104,105}$. During early life, sex does not influence the microbiome composition. Deep sequencing of colonic contents in pre-pubescent mice report no sex difference in bacterial community composition, suggesting that sex does not influence the microbiome in this age group ${ }^{106}$. A number of mouse studies, however, show sex differences in host gene expression in the gastrointestinal tract before puberty, demonstrating that sex-specific gene regulation occurs even in the absence of high levels of circulating sex hormones ${ }^{106}$. After puberty, female rodents have lower frequencies of Bacteroidetes than males ${ }^{104,105}$.

In a mouse model of spontaneous type 1 diabetes, adoptive transfer of gut commensals from male mice into females resulted in systemic hormonal changes and protected against disease ${ }^{104,105}$. Similar to what is seen in mice, the human female microbiome is less abundant in Bacteroidetes spp. than males ${ }^{107}$. A study specifically analysing for a sex-diet interaction in diverse vertebrate species including fish, mice, and humans confirmed that diet has sex-specific effects on the gut microbiome in two species of fish, affects Fusobacteria spp. levels in humans, but does not seem to affect the microbiome in laboratory mice ${ }^{108}$. The lack of effect of diet on sex difference in the gut microbiome in laboratory mice may reflect the highly simplified diets they are fed and the artificial environment in which they are maintained ${ }^{109}$. Whether sex differences in the effects of diet on the gut microbiome in humans contributes to sex differences in diseases associated with dysbiosis, such as inflammatory bowel disease requires consideration. These data also imply that therapeutic approaches to treat diseases associated with dysbiosis may need to be different for males and females.

\section{Effects of age and reproductive status}

The age and reproductive status of an individual are also important determinants of sex-related differences in immune responses (FIG. 1). In the following section, we highlight some of the key immunological differences that are seen between the sexes at different stages of life. 
In utero. Adverse fetal conditions may cause epigenetic adaptations leading to altered gene activity that can persist throughout life, including immunological programming ${ }^{110}$. Sex-differential developmental programming in utero results in sex differences in the local milieu and immune system development. Female fetuses have greater adaptability to intra-uterine stress than males. The placentas from premature (that is, born at $<32$ weeks gestation) male fetuses tend to be more chronically inflamed compared with those from female fetuses ${ }^{111}$, providing females survival benefits from better cardiovascular stability and lower levels of circulating cytokines. Human male testes produce androgens from 10 weeks of gestation ${ }^{112}$, leading to early development of androgen-dependent sex differences in immunity. Male neonates have higher cord blood IgE levels than females ${ }^{113}$, a fetal product that may predict the development of atopy.

Birth to 5 years of age. At birth the fetus transitions from the placenta to the outside environment and is bombarded with new antigens. Multiple studies have investigated neonatal immunity using cord blood samples due to the availability of large blood volumes, but few have specifically looked for sex differences. Cord blood mononuclear cell reactivity to TLR agonists in full term infants and pre-term infants that were born at $<33$ weeks of gestation is not affected by sex in either group $^{114}$. However, human male infants have higher monocyte and basophil counts compared to females up until 13 months of age, at least in high pathogen burden settings ${ }^{115}$. NK cell frequencies are higher in male than female children ${ }^{25}$. Infant males have greater proinflammatory responses than females following stimulation with either LPS or mitogens ${ }^{116}$, all suggesting that males develop more robust innate immunity compared with females in early life.

Female cord blood contains higher numbers of $\mathrm{CD}^{+} \mathrm{T}$ cells, higher CD4/CD8 $\mathrm{T}$ cell ratios and lower numbers of $\mathrm{CD}^{+} \mathrm{T}$ cells and NK cells than cord blood from males, and these differences persist throughout childhood. By contrast, B cell numbers are comparable in male and female children ${ }^{25,26}$. The existence of these sex differences before puberty is often interpreted as evidence for genetic differences between the sexes. Neonatal castration experiments in rodents illustrate that the neonatal sex steroid milieu influences thymic development causing sex differences in the peripheral $\mathrm{T}$ cell compartment, including lower CD4/CD8 T cell ratios and higher $\mathrm{NK} \mathrm{T}$ cell and $\mathrm{CD} 4^{+} \mathrm{CD} 25^{+} \mathrm{FOXP} 3^{+}$ $\mathrm{T}_{\text {reg }}$ cell numbers in neonatal males ${ }^{117}$. By contrast, there are no sex differences in human $\mathrm{T}_{\text {reg }}$ cell frequencies in Australian infants from birth to one year of age ${ }^{118}$. Nigerian female children (aged 5-12 years) have lower IgA levels, but equivalent IgG and IgM levels, compared with males ${ }^{119}$.

Puberty. The multiple effects of sex steroids on immune cells play a prominent role in sex differences in inflammatory status during puberty. Although infant males may produce higher inflammatory responses than females, after puberty inflammatory responses are consistently higher in females than in males ${ }^{120}$. Females continue to have higher $\mathrm{CD} 4^{+} \mathrm{T}$ cell counts and higher CD4/CD8 $\mathrm{T}$ cell ratios than males throughout adulthood $^{27,121}$, whereas males have higher numbers of $\mathrm{T}_{\text {reg }}$ cells $^{33}$. Gene expression studies in mice show that post-pubertal females show increased expression of genes associated with the adaptive immune response (for example, immunoglobulin and B cell receptor genes), whereas males show increased expression of genes that are associated with innate responses (for example, serum amyloid A, haptoglobin and plasminogen activator inhibitor 2 as well as $C c l 9$ and $C c r 1)^{122}$.

Because sex steroids profoundly affect the immune response, it is not surprising that hormonal changes during the female menstrual cycle underlie cyclical changes in immune function and exacerbation of diseases, with pronounced fluctuations in immune cell numbers and function occurring over the menstrual cycle, including increased numbers of $\mathrm{T}_{\text {reg }}$ cells when $\mathrm{E} 2$ concentrations are highest before ovulation ${ }^{123}$.

Reproductive senescence. Women, worldwide, have a longer lifespan than males, with biological factors, including changes in sex steroid concentrations and $\mathrm{X}$ chromosome diploidy, having a significant role ${ }^{124}$. With age, concentrations of sex steroids decline rapidly for females and more gradually for males, paralleling a progressive functional decline in the immune system of both sexes ${ }^{125}$. One of the most well characterized attributes of an ageing immune system is an aberrant chronic low-grade pro-inflammatory state, thought to occur to a greater extent in females than males ${ }^{35}$. NK cell numbers increase with age, with the kinetics of this rise being greater for females than males ${ }^{126}$. Female menopause is associated with a decline in certain lymphocyte subsets, but elderly males experience a more rapid decline in numbers of B cells and various $\mathrm{CD} 4^{+} \mathrm{T}$ cell subsets and show lower levels of $\mathrm{T}$ cell proliferation than females, along with a more modest increase in $\mathrm{CD} 4^{+}$memory $\mathrm{T}$ cells following antigen re-exposure $\mathrm{e}^{34,126}$. A population of B cells referred to as 'age-associated B cells' has been linked with the development of autoimmune diseases in mice and humans, and these cells are found in higher frequencies in aged female mice than in aged male mice ${ }^{127}$.

\section{Sex differences in the pathogenesis of diseases}

Autoimmune diseases. Women represent $\sim 80 \%$ of all cases of autoimmunity in the US ${ }^{128}$. Sex differences in the incidence of autoimmunity are most pronounced for Sjögren syndrome, systemic lupus erythematosus, thyroid diseases (such as Hashimoto thyroiditis and Graves disease), scleroderma, and myasthenia gravis, with significantly more women afflicted than men (FIG. 2). Although less common, there are some autoimmune diseases, including myocarditis and idiopathic pulmonary fibrosis, that show greater incidence in males than females, which is hypothesized to reflect higher $\mathrm{T}_{\mathrm{H}} 1$ cell responses to self antigens during the acute phase of these autoimmune diseases ${ }^{129}$. 


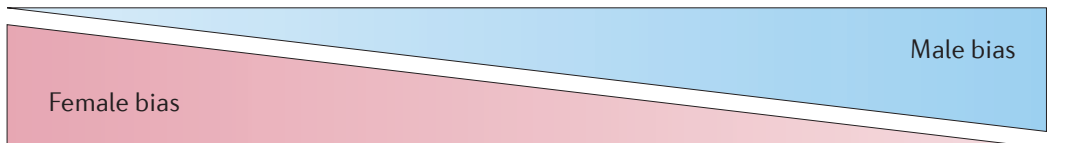

\begin{tabular}{|c|c|c|c|}
\hline Autoimmune diseases & \multicolumn{2}{|c|}{ Infectious diseases } & $\begin{array}{l}\text { Non-reproductive } \\
\text { cancers }\end{array}$ \\
\hline $\begin{array}{l}\text { - Graves disease } \\
\text { - Hashimoto thyroiditis } \\
\text { - Multiple sclerosis } \\
\text { - Rheumatoid arthritis } \\
\text { - Systemic lupus } \\
\text { erythematosis } \\
\text { - Type } 1 \text { diabetes }\end{array}$ & $\begin{array}{l}\text { - HIV } \\
\text { - Influenza } \\
\text { - Toxoplasmosis } \\
\text { - Legionella } \\
\text { - Malaria } \\
\text { - Zika }\end{array}$ & $\begin{array}{l}\text { - Ebola } \\
\text { - MERS } \\
\text { - Hepatitis B } \\
\text { - Tuberculosis } \\
\text { - Leptospirosis } \\
\text { - Campylobacter } \\
\text { - Schistosomiasis } \\
\text { - Amebiasis } \\
\text { - Aspergillosis }\end{array}$ & $\begin{array}{l}\text { - Bladder } \\
\text { - Bowel } \\
\text { - Kidney } \\
\text { - Leukaemia } \\
\text { - Liver } \\
\text { - Lung } \\
\text { - Malignant melanoma } \\
\text { - Oesophagus } \\
\text { - Stomach }\end{array}$ \\
\hline
\end{tabular}

Figure 2 | Sex bias in infectious diseases, inflammatory diseases and cancers. At the extremes, males and females show robust differences in their susceptibility to autoimmunity and cancers. Generally, females show increased susceptibility to autoimmune disease development and males show increased susceptibility to nonreproductive malignant cancers. Although at a less pronounced magnitude, sex differences are also seen in susceptibility to various infectious diseases. Reproductive status, including pregnancy, as well as immune-mediated pathology contributes to female-biased infectious diseases, whereas pathogen-associated damage, including delayed clearance, is associated with male-biased infectious diseases. MERS, Middle East respiratory syndrome. oesophagus, bladder and lung cancers ${ }^{134}$. This malebiased mortality is hypothesized to reflect differences in cancer aetiology ${ }^{134}$, including sex differences in viral infection, immune function, hormonal regulation, gene expression, sex chromosome complement, oxidative damage, autophagy, or a combination of factors ${ }^{134,135}$. Even treatments for cancers show sex-specific outcomes. Immune checkpoint inhibitors are revolutionizing cancer treatment, and some treatments, including programmed cell death 1 ligand 1 (PDL1)-specific monoclonal antibodies, appear to be more efficacious in female patients compared with male patients with melanoma ${ }^{136}$. The sex-differential effects of cancer chemotherapies with immunomodulatory properties and cancer vaccines require dedicated research.

Infectious diseases. The sexes differ in the severity, prevalence, and pathogenesis of infections caused by viruses, bacteria, parasites and fungi, with males generally more susceptible to these infections than females ${ }^{137}$ (FIG. 2). These differences are observed for infectious diseases acquired via multiple routes such as personto-person, vector-borne, blood-borne, and food and water borne ${ }^{124}$, with sex differences in immunity playing a major role ${ }^{138}$. Newborn males are more vulnerable to infections and death than females ${ }^{139}$. In several developing countries, school-age male children have higher rates of protozoan infections (such as, malaria caused by Plasmodium falciparum, visceral leishmaniasis and Entameba histolytica induced amoebic liver abscess), trematode infections (such as, schistosomiasis caused by Schistosoma mansoni) and nematode infections (such as those with Necator americanus, Toxocara spp. and Wuchereria bancrofti $)^{140}$. Among adults, untreated HIV-1-infected women have greater $\mathrm{CD} 8^{+} \mathrm{T}$ cell activation than men when adjusted for viral load and over 40\% less circulating HIV RNA than men; however, when matched with men by HIV RNA load, woman have a 1.6-fold higher risk of developing AIDS ${ }^{141}$. Although exposure to influenza A viruses is often higher in men, fatality following exposure to pathogenic influenza A viruses is higher in women; by contrast, the prevalence of serum hepatitis B virus (HBV) surface antigen, HBV DNA titers and development of hepatocellular carcinoma is higher in men than women. In most countries, tuberculosis notification is twice as high for men than women. Clinical cryptococcosis is 10 times higher for immunocompromised men than women. Heightened immunity to pathogens among females contributes to lower intensity (that is viral load within an individual) and prevalence (that is number of infected individuals within a population) of many infections for females than males, but it may increase disease symptoms and severity among females compared with males ${ }^{137}$.

Vaccines. Sex differences have been described in immunity to multiple vaccines, including both inactivated vaccines (such as vaccines against brucellosis, diphtheria, hepatitis $A$, hepatitis $B$, herpes simplex virus-2 infection (genital herpes), influenza, meningococcal 
Table 4 | Sex differences in responses to vaccines in humans

\begin{tabular}{|c|c|c|c|c|}
\hline $\begin{array}{l}\text { Target } \\
\text { group }\end{array}$ & Vaccine & $\begin{array}{l}\text { Sex difference in } \\
\text { Immune response }\end{array}$ & $\begin{array}{l}\text { Sex difference in } \\
\text { adverse reactions }\end{array}$ & $\begin{array}{l}\text { Age } \\
\text { (years) }\end{array}$ \\
\hline \multirow[t]{8}{*}{ Children } & Hepatitis B & Greater in females & Not defined & $<12$ \\
\hline & Diphtheria & Greater in females & Not defined & $<2$ \\
\hline & Pertussis & Greater in females & Not defined & $<2$ \\
\hline & Pneumococcal & Greater in females & Not defined & $6-9$ \\
\hline & Rabies & Greater in females & Not defined & $6-9$ \\
\hline & Measles & $\begin{array}{l}\text { Greater in females } \\
\text { or equivalent in } \\
\text { both sexes }\end{array}$ & Increased in females & $<3$ \\
\hline & $\begin{array}{l}\text { RTS,S vaccine } \\
\text { against malaria }\end{array}$ & Greater in females & Increased in females & $<2$ \\
\hline & $\begin{array}{l}\text { Human } \\
\text { papillomavirus }\end{array}$ & Greater in females & Increased in females & $5-17$ \\
\hline \multirow[t]{6}{*}{ Adults } & Influenza & Greater in females & Increased in females & $18-49$ \\
\hline & Hepatitis B & Greater in females & Increased in females & $>18$ \\
\hline & Herpes virus & Greater in females & Not defined & $>18$ \\
\hline & Yellow fever & Greater in females & Increased in females & $>18$ \\
\hline & Rabies & Greater in females & Not defined & $>18$ \\
\hline & Smallpox & Greater in females & Not defined & $>18$ \\
\hline \multirow{4}{*}{$\begin{array}{l}\text { Aged } \\
\text { adults }\end{array}$} & Influenza & Greater in females & Increased in females & $>65$ \\
\hline & $\mathrm{Td} / \mathrm{Tdap}$ & Greater in males & Increased in females & $>65$ \\
\hline & Pneumococcal & Greater in males & Increased in females & $>65$ \\
\hline & Shingles & Not defined & Increased in females & $>65$ \\
\hline
\end{tabular}

meningitis, pneumococcal disease (using pneumococcal polysaccharide), rabies and tetanus) and live vaccines (such as those against measles, rubella, smallpox, Venezuelan equine encephalitis, and yellow fever), in both children and adults ${ }^{142}$. The biological differences between the sexes is a major source of variation in the immune response to vaccination ${ }^{11,124}$ (TABLE 4).
Antibody responses to bacterial and viral vaccines are often higher in females than males (TABLE 4). This could mean that the effective vaccine dose is lower for females than for males. For example, in dose response studies with the inactivated influenza vaccine, human females vaccinated with a half dose influenza vaccine achieved equivalent antibody titres to males vaccinated with full dose vaccine ${ }^{143}$. Females consistently report more frequent and severe local and systemic reactions to viral and bacterial vaccines than males, at least among young and ageing adults ${ }^{11,124,142}$, reflecting either a reporting bias or greater inflammatory responses among females than males ${ }^{11}$. Whether sex differences in immune responses to vaccines are caused by genetic, hormonal and environmental factors, or a combination, requires consideration.

\section{Conclusions and perspective}

The basis for personalized medicine is that unique aspects of our biology, including our immune responses, will define novel targets for more effective prevention and treatment of immune-related diseases. In this Review, we provide evidence that sex is one variable that influences innate and adaptive immune responses, resulting in sex-specific outcomes from infectious and autoimmune diseases, malignancies, and vaccines. If the long-term goal of personalizing treatments for immune-mediated diseases is effective treatment for all individuals, then will we ultimately treat males and females differently in an effort to protect them equally? Future studies must identify the precise factors mediating sex differences in the immune responses, knowing that this will probably reflect complex interactions among hormones, genes and our environment (both biotic and abiotic). Sex-based differences in the activity of the innate and adaptive immune responses likely have evolved through a process of convergent evolution, in which the fundamental mechanisms that underlie increased survival and reproductive success have sex-specific effects on immune function.
1. Beery, A. K. \& Zucker, I. Sex bias in neuroscience and biomedical research. Neurosci. Biobehav Rev. 35 , 565-572 (2011).

2. Zuk, M. The sicker sex. PLoS Pathog. 5, e 1000267 (2009).

3. Hill-Burns, E. M. \& Clark, A. G. X-Linked variation in immune response in Drosophila melanogaster. Genetics 183, 1477-1491 (2009).

4. Taylor, K. \& Kimbrell, D. A. Host immune response and differential survival of the sexes in Drosophila. Fly (Austin) 1, 197-204 (2007).

5. Mondal, S. \& Rai, U. Sexual dimorphism in phagocytic activity of wall lizard's splenic macrophage and its control by sex steroids. Gen. Comp. Endocrinol. 116, 291-298 (1999)

6. Pap, P. L., Czirjak, G. A., Vagasi, C. I., Barta, Z. \& Hasselquist, D. Sexual dimorphism in immune function changes during the annual cycle in house sparrows. Naturwissenschaften 97, 891-901 (2010).

7. Fargallo, J. A., Martinez-Padilla, J., Toledano-Diaz, A. Santiago-Moreno, J. \& Davila, J. A. Sex and testosterone effects on growth, immunity and melanin coloration of nestling Eurasian kestrels. J. Anim. Ecol. 76, 201-209 (2007)

8. Pisitkun, P. et al. Autoreactive B cell responses to RNA-related antigens due to $T L R 7$ gene duplication. Science 312, 1669-1672 (2006).
9. Berghofer, B. et al. TLR7 ligands induce higher IFN- $\alpha$ production in females. J. Immunol. 177, 2088-2096 (2006)

10. Griesbeck, M. et al. Sex differences in plasmacytoid dendritic cell levels of IRF5 drive higher IFN- $\alpha$ production in women. J. Immunol. 195, 5327-5336 (2015).

This study provides mechanistic insights into the cellular mechanisms mediating sex differences in antiviral immunity in humans.

11. Klein, S. L., Jedlicka, A. \& Pekosz, A. The Xs and $Y$ of immune responses to viral vaccines. Lancet Infect. Dis. 10, 338-349 (2010).

This thorough review provides details about sex differences in immune responses, including transcriptional activation, and adverse reactions to vaccines in humans and animal models.

12. Hannah, M. F., Bajic, V. B. \& Klein, S. L. Sex differences in the recognition of and innate antiviral responses to Seoul virus in Norway rats. Brain Behav. Immun 22, 503-516 (2008).

13. Torcia, M. G. et al. Sex differences in the response to viral infections: TLR8 and TLR9 ligand stimulation induce higher IL-10 production in males. PLOS ONE 7, e39853 (2012)

14. Moxley, G. et al. Sexual dimorphism in innate immunity. Arthritis Rheum. 46, 250-258 (2002).
15. Asai, K et al. Gender differences in cytokine secretion by human peripheral blood mononuclear cells: role of estrogen in modulating LPS-induced cytokine secretion in an ex vivo septic model. Shock 16, 340-343 (2001).

16. Aomatsu, M., Kato, T., Kasahara, E. \& Kitagawa, S. Gender difference in tumor necrosis factor- $\alpha$ production in human neutrophils stimulated by lipopolysaccharide and interferon- $\gamma$. Biochem. Biophys. Res. Commun. 441, 220-225 (2013)

17. Marriott, I., Bost, K. L. \& Huet-Hudson, Y. M. Sexual dimorphism in expression of receptors for bacterial lipopolysaccharides in murine macrophages: a possible mechanism for genderbased differences in endotoxic shock susceptibility. J. Reprod. Immunol. 71, 12-27 (2006).

The first study to document sex differences in TLR4 activation and disease outcome.

18. Rettew, J. A., Huet-Hudson, Y. M. \& Marriott, I. Testosterone reduces macrophage expression in the mouse of toll-like receptor 4, a trigger for inflammation and innate immunity. Biol. Reprod. 78, 432-437 (2008).

19. Abdullah, M. et al. Gender effect on in vitro lymphocyte subset levels of healthy individuals. Cell. Immunol. 272, 214-219 (2012). 
20. Spitzer, J. A. Gender differences in some host defense mechanisms. Lupus 8, 380-383 (1999)

21. Weinstein, Y., Ran, S. \& Segal, S. Sex-associated differences in the regulation of immune responses controlled by the MHC of the mouse. J. Immunol. 132 656-661 (1984).

22. Russi, A. E., Walker-Caulfield, M. E., Ebel, M. E. ¿ Brown, M. A. Cutting edge: c-Kit signaling differentially regulates type 2 innate lymphoid cell accumulation and susceptibility to central nervous system demyelination in male and female SJL mice. J. Immunol. 194, 5609-5613 (2015). The first documentation of sex differences in innate lymphoid cells, with direct implications for sex differential susceptibility to an autoimmune disease.

23. Leposavic, G., Pilipovic, I. \& Perisic, M. Cellular and nerve fibre catecholaminergic thymic network: steroid hormone dependent activity. Physiol. Res. 60 (Suppl. 1), S71-S82 (2011).

24. Leposavic, G., Karapetrovic, B., Obradovic, S. Vidiic Dandovic, B. \& Kosec, D. Differential effects of gonadectomy on the thymocyte phenotypic profile in male and female rats. Pharmacol. Biochem. Behav. 54, 269-276 (1996)

25. Lee, B. W. et al. Age- and sex-related changes in lymphocyte subpopulations of healthy Asian subjects: from birth to adulthood. Cytometry 26 8-15 (1996)

26. Lisse, I. M. et al. T-Lymphocyte subsets in West African children: impact of age, sex, and season. J. Pediatr. 130, 77-85 (1997).

27. Uppal, S. S., Verma, S. \& Dhot, P. S. Normal values of CD4 and CD8 lymphocyte subsets in healthy indian adults and the effects of sex, age, ethnicity, and smoking. Cytometry B Clin. Cytom. 52, 32-36 (2003).

28. Sankaran-Walters, S. et al. Sex differences matter in the gut: effect on mucosal immune activation and inflammation. Biol. Sex Differ. 4, 10 (2013).

29. Hewagama, A., Patel, D., Yarlagadda, S. Strickland, F. M. \& Richardson, B. C. Stronger inflammatory/cytotoxic T-cell response in women identified by microarray analysis. Genes Immun. 10 509-516 (2009).

30. Roberts, C. W., Walker, W. \& Alexander, J. Sex-associated hormones and immunity to protozoan parasites. Clin. Microbiol. Rev. 14, 476-488 (2001).

31. Giron-Gonzalez, J. A. et al. Consistent production of a higher TH1:TH2 cytokine ratio by stimulated T cells in men compared with women. Eur. J. Endocrinol. 143, 31-36 (2000)

32. Zhang, M. A. et al. Peroxisome proliferator-activated receptor (PPAR) $\alpha$ and $-\gamma$ regulate IFN $\gamma$ and IL-17A production by human T cells in a sex-specific way. Proc. Natl Acad. Sci. USA 109, 9505-9510 (2012)

33. Afshan, G., Afzal, N. \& Qureshi, S. CD4 ${ }^{+}$CD25(hi) regulatory $T$ cells in healthy males and females mediate gender difference in the prevalence of autoimmune diseases. Clin. Lab. 58, 567-571 (2012).

34. Teixeira, D. et al. Evaluation of lymphocyte levels in a random sample of 218 elderly individuals from Sao Paulo city. Rev. Bras. Hematol. Hemoter. 33 367-371 (2011).

35. Furman, D. et al. Systems analysis of sex differences reveals an immunosuppressive role for testosterone in the response to influenza vaccination. Proc. Natl Acad. Sci. USA 111, 869-874 (2014).

This systems biology study identifies a testosteronesensitive gene cluster involved in lipid biosynthesis that correlates with lower protective antibody responses to seasonal influenza vaccination in men.

36. Fan, H. et al. Gender differences of B cell signature in healthy subjects underlie disparities in incidence and course of SLE related to estrogen. J. Immunol. Res. 2014, 814598 (2014).

37. Libert, C., Dejager, L. \& Pinheiro, I. The X chromosome in immune functions: when a chromosome makes the difference Nat Rev Immunol 10, 594-604 (2010). This paper reviews the major mechanisms responsible for higher immune activity in females as compared with men.

38. Case, L. K. et al. Chromosome Y regulates survival following murine coxsackievirus b3 infection. G3 (Bethesda) 2, 115-121 (2012)

39. Smith-Bouvier, D. L. et al. A role for sex chromosome complement in the female bias in autoimmune disease. J. Exp. Med. 205, 1099-1108 (2008) A mouse study of two models of autoimmun disease providing the first evidence that the
XX chromosome complement confers greater susceptibility to autoimmunity than the $X Y$ sex chromosome complement.

40. Robinson, D. P. et al. Sex chromosome complement contributes to sex differences in coxsackievirus B3 but not influenza A virus pathogenesis. Biol. Sex Differ. 2 8 (2011).

41. Kocar, I. H. et al. The effect of testosterone replacement treatment on immunological features of patients with Klinefelter's syndrome. Clin. Exp. Immunol. 121, 448-452 (2000).

42. Bianchi, I., Lleo, A., Gershwin, M. E. \& Invernizzi, P. The $\mathrm{X}$ chromosome and immune associated genes. J. Autoimmun. 38, J187-J192 (2012)

43. Cacciari, E. et al. Serum immunoglobulins and lymphocyte subpopulations derangement in Turner's syndrome. J. Immunogenet. 8, 337-344 (1981)

44. Sharma, S. \& Eghbali, M. Influence of sex differences on microRNA gene regulation in disease. Biol. Sex Differ. 5, 3 (2014).

45. Ghorai, A. \& Ghosh, U. miRNA gene counts in chromosomes vary widely in a species and biogenesis of miRNA largely depends on transcription or post-transcriptional processing of coding genes. Front. Genet. 5, 100 (2014)

46. Pinheiro, I., Dejager, L. \& Libert, C. X-Chromosomelocated microRNAs in immunity: might they explain male/female differences? The $\mathrm{X}$ chromosome-genomic context may affect X-located miRNAs and downstream signaling, thereby contributing to the enhanced immune response of females. BioEssays 33, 791-802 (2011)

One of the first papers to hypothesize that X-linked miRNAs play a major part in the sex differences in immunity between males and females.

47. Dai, R. et al. Sex differences in the expression of lupus-associated miRNAs in splenocytes from lupus prone NZB/WF1 mice. Biol. Sex Differ. 4, 19 (2013).

48. Zhang, Y. \& Cao, X. Long noncoding RNAs in innate immunity. Cell. Mol. Immunol. 13, 138-147 (2016).

49. Gayen, S., Maclary, E., Hinten, M. \& Kalantry, S. Sex-specific silencing of X-linked genes by Xist RNA. Proc. Natl Acad. Sci. USA 113, E309-E318 (2016).

50. Baynam, G. et al. Gender-specific effects of cytokine gene polymorphisms on childhood vaccine responses. Vaccine 26, 3574-3579 (2008).

51. Phiel, K. L., Henderson, R. A., Adelman, S. J. \& Elloso, M. M. Differential estrogen receptor gene expression in human peripheral blood mononuclear cell populations. Immunol. Lett. 97, 107-113 (2005).

52. Kovats, S. Estrogen receptors regulate innate immune cells and signaling pathways. Cell. Immunol. 294, 63-69 (2015)

53. Jilma, B. et al. Effects of $17 \beta$-estradiol on circulating adhesion molecules. J. Clin. Endocrinol. Metab. 79, 1619-1624 (1994)

54. Robinson, D. P., Hall, O. J., Nilles, T. L., Bream, J. H. \& Klein, S. L. 17 $\beta$-estradiol protects females against influenza by recruiting neutrophils and increasing virus-specific CD8 T cell responses in the lungs. J. Virol. 88, 4711-4720 (2014).

55. Nakaya, M., Tachibana, H. \& Yamada, K. Effect of estrogens on the interferon- $\gamma$ producing cell population of mouse splenocytes. Biosci. Biotechnol. Biochem. 70, 47-53 (2006)

56. Hao, S. et al. Modulation of $17 \beta$-estradiol on the number and cytotoxicity of NK cells in vivo related to $\mathrm{MCM}$ and activating receptors. Int. Immunopharmacol. 7, 1765-1775 (2007)

57. Bouman, A., Heineman, M. J. \& Faas, M. M Sex hormones and the immune response in humans. Hum. Reprod. Update 11, 411-423 (2005).

58. Rettew, J. A., Huet, Y. M. \& Marriott, I. Estrogens augment cell surface TLR4 expression on murine macrophages and regulate sepsis susceptibility in vivo. Endocrinology 150, 3877-3884 (2009).

59. Paharkova-Vatchkova, V., Maldonado, R. \& Kovats, S. Estrogen preferentially promotes the differentiation of $C D 11 c^{+} C D 11$ bint dendritic cells from bone marrow precursors. J. Immunol. 172, 1426-1436 (2004). A rigorous evaluation of oestrogenic effects on DC differentiation and ER expression.

60. Bengtsson, A. K., Ryan, E. J., Giordano, D., Magaletti, D. M. \& Clark, E. A. 17 $\beta$-estradiol (E2) modulates cytokine and chemokine expression in human monocyte-derived dendritic cells. Blood 104 1404-1410 (2004)

61. Siracusa, M. C. Overstreet, M. G., Housseau, F., Scott, A. L. \& Klein, S. L. 17 $\beta$-estradiol alters the activity of conventional and IFN-producing killer dendritic cells. J. Immunol 180, 1423-1431 (2008)

62. Miller, L. \& Hunt, J. S. Sex steroid hormones and macrophage function. Life Sci. 59, 1-14 (1996).

63. Seillet, C. et al. The TLR-mediated response of plasmacytoid dendritic cells is positively regulated by estradiol in vivo through cell-intrinsic estrogen receptor-a signaling. Blood 119, 454-464 (2012).

64. Straub, R. H. The complex role of estrogens in inflammation. Endocr. Rev. 28, 521-574 (2007). An excellent review of oestrogenic effects on immune cells and immune-mediated diseases, with exceptional details about in vitro and in vivo studies, concentrations of oestrogen and identification of the biopotential effects of oestrogens on immune responses.

65. Fox, H. S., Bond, B. L. \& Parslow, T. G. Estrogen regulates the IFN- $\gamma$ promoter. J. Immunol. 146 4362-4367 (1991)

66. Suzuki, T. et al Mitogen activated protein kinase (MAPK) mediates non-genomic pathway of estrogen on T cell cytokine production following traumahemorrhage. Cytokine 42, 32-38 (2008)

67. Karpuzoglu, E., Phillips, R. A., Gogal, R. M. \& Ansar Ahmed, S. IFN- $\gamma$-inducing transcription factor T-bet is upregulated by estrogen in murine splenocytes: role of IL-27 but not IL-12. Mol. Immunol. 44 1808-1814 (2007)

An excellent example of the molecular mechanisms mediating how sex steroids, specifically oestrogens, regulate the functioning of immune cells in vivo.

68. Dai, R. et al. Suppression of LPS-induced Interferon- $\gamma$ and nitric oxide in splenic lymphocytes by select estrogen-regulated microRNAs: a novel mechanism of immune modulation. Blood 112, 4591-4597 (2008).

69. Polanczyk, M. J. et al. Cutting edge: estrogen drives expansion of the $\mathrm{CD} 4{ }^{+} \mathrm{CD} 25^{+}$regulatory $\mathrm{T}$ cell compartment. J. Immunol. 173, 2227-2230 (2004). One of the first papers describing direct effects of sex steroids, specifically oestrogens, affecting a specific $\mathrm{T}$ cell population

70. Dinesh, R. K., Hahn, B. H. \& Singh, R. P. Gender and sex hormones influence $C D 4$ regulatory $T$ cells and their expression of FoxP3 in healthy people and in SLE. Arthritis Rheum. Abstr. 62 (Suppl. 10), 1257 (2010)

71. Wang, C. et al. Oestrogen modulates experimental autoimmune encephalomyelitis and interleukin-17 production via programmed death 1. Immunology 126, 329-335 (2009).

72. Tyagi, A. M. et al. Estrogen deficiency induces the differentiation of IL-17 secreting $T_{H} 17$ cells: a new candidate in the pathogenesis of osteoporosis. PIOS ONE 7, e44552 (2012)

73. Lu, F. X. et al. The strength of B cell immunity in female rhesus macaques is controlled by $\mathrm{CD} 8^{+} \mathrm{T}$ cells under the influence of ovarian steroid hormones. Clin. Exp. Immunol. 128, 10-20 (2002).

74. Pauklin, S., Sernandez, I. V., Bachmann, G., Ramiro, A. R. \& Petersen-Mahrt, S. K. Estrogen directly activates AID transcription and function. J. Exp. Med. 206, 99-111 (2009).

75. Teilmann, S. C., Clement, C. A., Thorup, J., Byskov, A. G. \& Christensen, S. T. Expression and localization of the progesterone receptor in mouse and human reproductive organs. J. Endocrinol. 191 525-535 (2006)

76. Butts, C. L. et al. Progesterone inhibits mature rat dendritic cells in a receptor-mediated fashion. Int. Immunol. 19, 287-296 (2007)

77. Jones, L. A. et al. Differential modulation of TLR3- and TLR4-mediated dendritic cell maturation and function by progesterone. J. Immunol. 185, 4525-4534 (2010).

Mechanistic details about how progesterone signalling through progesterone receptors affects DC maturation and function.

78. Menzies, F. M., Henriquez, F. L., Alexander, J. \& Roberts, C. W. Selective inhibition and augmentation of alternative macrophage activation by progesterone. Immunology 134, 281-291 (2011)

79. Hardy, D. B., Janowski, B. A., Corey, D. R. \& Mendelson, C. R. Progesterone receptor plays a majo antiinflammatory role in human myometrial cells by antagonism of nuclear factor- $\mathrm{kB}$ activation of cyclooxygenase 2 expression. Mol. Endocrinol. 20, 2724-2733 (2006).

80. Arruvito, L. et al. NK cells expressing a progesterone receptor are susceptible to progesterone-induced apoptosis. J. Immunol. 180, 5746-5753 (2008) 
81. Piccinni, M. P. et al. Progesterone favors the development of human T helper cells producing $\mathrm{T}_{\mathrm{H}} 2$-type cytokines and promotes both IL-4 production and membrane CD30 expression in established $\mathrm{T}_{\mathrm{H}} 1$ cell clones. J. Immunol. 155 128-133 (1995).

82. Lee, J. H., Ulrich, B., Cho, J., Park, J. \& Kim, C. H. Progesterone promotes differentiation of human cord blood fetal $\mathrm{T}$ cells into $\mathrm{T}$ regulatory cells but suppresses their differentiation into $\mathrm{T}_{H} 17$ cells. J. Immunol. 187, 1778-1787 (2011).

83. Hou, J. \& Zheng, W. F. Effect of sex hormones on NK and ADCC activity of mice. Int. J. Immunopharmacol. 10, 15-22 (1988)

84. D'Agostino, P. et al. Sex hormones modulate inflammatory mediators produced by macrophages. Ann. NY Acad. Sci. 876, 426-429 (1999)

85. Liva, S. M. \& Voskuhl, R. R. Testosterone acts directly on $\mathrm{CD} 4{ }^{+} \mathrm{T}$ lymphocytes to increase IL-10 production. J. Immunol. 167, 2060-2067 (2001)

86. Pergola, C. et al. ERK-mediated regulation of leukotriene biosynthesis by androgens: a molecular basis for gender differences in inflammation and asthma. Proc. Natl Acad. Sci. USA 105, 19881-19886 (2008).

87. Musabak, U. et al. Gonadotropin treatment restores in vitro interleukin- $1 \beta$ and tumour necrosis factor- $\alpha$ production by stimulated peripheral blood mononuclear cells from patients with idiopathic hypogonadotropic hypogonadism. Clin. Exp. Immunol. 132, 265-270 (2003).

88. Malkin, C. J. et al. The effect of testosterone replacement on endogenous inflammatory cytokines and lipid profiles in hypogonadal men. J. Clin. Endocrinol. Metab. 89, 3313-3318 (2004)

89. Kalinchenko, S. Y et al. Effects of testosterone supplementation on markers of the metabolic syndrome and inflammation in hypogonadal men with the metabolic syndrome: the double-blinded placebocontrolled Moscow study. Clin. Endocrinol. (Oxf.) 73, 602-612 (2010)

90. Bobjer, J., Katrinaki, M., Tsatsanis, C., Lundberg Giwercman, Y. \& Giwercman, A. Negative association between testosterone concentration and inflammatory markers in young men: a nested cross-sectional study. PLoS ONE 8, e61466 (2013).

91. Page, S. T. et al. Effect of medical castration on CD4+ $\mathrm{CD} 25^{+} \mathrm{T}$ cells, CD8 ${ }^{+} \mathrm{T}$ cell IFN- $\gamma$ expression, and NK cells: a physiological role for testosterone and/or its metabolites. Am. J.Physiol. Endocrinol. Metabolism 290, E856-E863 (2006)

92. Roden, A. C. et al. Augmentation of T cell levels and responses induced by androgen deprivation. J. Immunol. 173, 6098-6108 (2004).

93. Lin, A. A., Wojciechowski, S. E. \& Hildeman, D. A Androgens suppress antigen-specific T cell responses and IFN- $\gamma$ production during intracranial LCMV infection. J. Neuroimmunol. 226, 8-19 (2010).

94. Lotter, H. et al. Testosterone increases susceptibility to amebic liver abscess in mice and mediates inhibition of IFN $\gamma$ secretion in natural killer T cells. PLOS ONE 8 e55694 (2013).

95. McKay, L. I. \& Cidlowski, J. A. Molecular control of immune/inflammatory responses: interactions between nuclear factor-kB and steroid receptorsignaling pathways. Endocr. Rev. 20, 435-459 (1999).

96. Dunn, S. E. et al. Peroxisome proliferator-activated receptor (PPAR) a expression in T cells mediates gender differences in development of T cellmediated autoimmunity. J. Exp. Med. 204, 321-330 (2007).

A detailed in vivo examination of the molecular mechanisms through which androgens affect $T$ cell responses and the outcome of an autoimmune disease.

97. Khulan, B. et al. Periconceptional maternal micronutrient supplementation is associated with widespread gender related changes in the epigenome: a study of a unique resource in the Gambia. Hum. Mol. Genet. 21, 2086-2101 (2012) A double-blind controlled trial of maternal micronutrient supplementation demonstrating that peri-conceptional nutrition has sexdifferential epigenetic effects on genes involved in immunity.

98. Tobi, E. W. et al. DNA methylation differences after exposure to prenatal famine are common and timingand sex-specific. Hum. Mol. Genet. 18, 4046-4053 (2009).
99. Sinha, A., Madden, J., Ross-Degnan, D., Soumerai, S. \& Platt, R. Reduced risk of neonatal respiratory infections among breastfed girls but not boys. Pediatrics 112, e303 (2003)

100. Kawai, K. et al. Sex differences in the effects of maternal vitamin supplements on mortality and morbidity among children born to HIV-infected women in Tanzania. Br. J. Nutr. 103, 1784-1791 (2010).

101. Osrin, D. et al. Effects of antenatal multiple micronutrient supplementation on birthweight and gestational duration in Nepal: double-blind, randomised controlled trial. Lancet 365, 955-962 (2005).

102. Friis, H. et al. Effect of multimicronutrient supplementation on gestational length and birth size: a randomized, placebo-controlled, double-blind effectiveness trial in Zimbabwe. Am. J. Clin. Nutr. 80 178-184 (2004)

103. Jensen, K. J. et al. The effects of vitamin A supplementation with measles vaccine on leucocyte counts and in vitro cytokine production. Br. J. Nutr. 115, 619-628 (2016).

104. Markle, J. G. et al. Sex differences in the gut microbiome drive hormone-dependent regulation of autoimmunity. Science 339, 1084-1088 (2013). A mouse-based study demonstrating that the gut microbiota alters sex hormone levels, which in turn protect mice male from type 1 diabetes. Transfer of male microbiota to susceptible females provided robust protection against type 1 diabetes.

105. Yurkovetskiy, L. et al. Gender bias in autoimmunity is influenced by microbiota. Immunity $39,400-412$ (2013).

106. Steegenga, W. T. et al. Sexually dimorphic characteristics of the small intestine and colon of prepubescent C57BL/6 mice. Biol. Sex Differ. 5, 1 (2014).

107. Dominianni, C. et al. Sex, body mass index, and dietary fiber intake influence the human gut microbiome. PLOS ONE 10, e0124599 (2015).

108. Bolnick, D. I. et al. Individual diet has sex-dependent effects on vertebrate gut microbiota. Nat. Commun. 5 , 4500 (2014).

This paper demonstrates that diet affects the microbiota differently in males and females in humans and fish, suggesting that treatment of dysbiosis may need to be sex specific.

109. Bolnick, D. I. et al. Individuals' diet diversity influences gut microbial diversity in two freshwater fish (threespine stickleback and Eurasian perch). Ecol. Lett. 17, 979-987 (2014)

110. Gluckman, P. D., Hanson, M. A., Spencer, H. G. \& Bateson, P. Environmental influences during development and their later consequences for health and disease: implications for the interpretation of empirical studies. Proc. Biol. Sci. 272, 671-677 (2005).

111. Goldenberg, R. L. et al. The Alabama Preterm Birth Study: intrauterine infection and placental histologic findings in preterm births of males and females less than 32 weeks. Am. J. Obstet. Gynecol. 195 , 1533-1537 (2006).

112. Carr, B. R. et al. Regulation of human fetal testicular secretion of testosterone: low-density lipoproteincholesterol and cholesterol synthesized de novo as steroid precursor. Am. J. Obstet. Gynecol. 146 241-247 (1983)

113. Liu, C. A. et al. Prediction of elevated cord blood IgE levels by maternal IgE levels, and the neonate's gender and gestational age. Chang Gung Med. J. 26 561-569 (2003).

114. Sharma, A. A. et al. Hierarchical maturation of innate immune defences in very preterm neonates. Neonatology 106, 1-9 (2014).

115. Bellamy, G. J., Hinchliffe, R. F., Crawshaw, K. C., Finn, A. \& Bell, F. Total and differential leucocyte counts in infants at 2, 5 and 13 months of age. Clin. Lab. Haematol. 22, 81-87 (2000).

116. Casimir, G. J. et al. Gender differences and inflammation: an in vitro model of blood cells stimulation in prepubescent children. J. Inflamm (Lond.) 7, 28 (2010)

117. Leposavic, G., Perisic, M \& Pilipovic, I. Role of gonadal hormones in programming developmental changes in thymopoietic efficiency and sexual diergism in thymopoiesis. Immunol. Res. 52, 7-19 (2012).

118. Collier, F. M. et al. The ontogeny of naive and regulatory $\mathrm{CD} 4{ }^{+}$T-cell subsets during the first postnatal year: a cohort study. Clin. Transl. Immunology 4, e34 (2015).
119. Obiandu, C., Okerengwo, A. A. \& Dapper, D. V. Levels of serum immunoglobulins in apparently healthy children and adults in Port Harcourt, Nigeria. Niger. J. Physiol. Sci. 28, 23-27 (2013).

120. Yang, Y. \& Kozloski, M. Sex differences in age trajectories of physiological dysregulation: inflammation, metabolic syndrome, and allostatic load. J. Gerontol. A Biol. Sci. Med. Sci. 66, 493-500 (2011).

121. Wong, W. S. et al. Reference ranges for lymphocyte subsets among healthy Hong Kong Chinese adults by single-platform flow cytometry. Clin. Vaccine Immunol. 20, 602-606 (2013)

122. Lamason, R. et al. Sexual dimorphism in immune response genes as a function of puberty. BMC Immunol. 7, 2 (2006).

123. Arruvito, L., Sanz, M., Banham, A. H. \& Fainboim, Expansion of $\mathrm{CD}^{+}{ }^{+} \mathrm{CD} 25^{+}$and FOXP3 ${ }^{+}$regulatory $T$ cells during the follicular phase of the menstrual cycle: implications for human reproduction J. Immunol. 178, 2572-2578 (2007)

124. Giefing-Kroll, C., Berger, P., Lepperdinger, G. \& Grubeck-Loebenstein, B. How sex and age affect immune responses, susceptibility to infections, and response to vaccination. Aging Cell 14, 309-321 (2015)

This paper reviews the interplay between sex hormones and the aging immune system, suggesting that elderly women remain immune-privileged even in the face of declining sex hormone levels post menopause.

125. Castelo-Branco, C. \& Soveral, I. The immune system and aging: a review. Gynecol. Endocrinol. 30, 16-22 (2014)

126. Hirokawa, K. et al. Slower immune system aging in women versus men in the Japanese population. Immun. Ageing 10, 19 (2013).

127. Rubtsov, A. V. et al. Toll-like receptor 7 (TLR7)-driven accumulation of a novel CD $11 \mathrm{C}^{+} \mathrm{B}$-cell population is important for the development of autoimmunity. Blood 118, 1305-1315 (2011).

128. Jacobson, D. L., Gange, S. J., Rose, N. R. \& Graham, N. M. Epidemiology and estimated population burden of selected autoimmune diseases in the United States. Clin. Immunol. Immunopathol. 84, 223-243 (1997)

129. Fairweather, D., Frisancho-Kiss, S. \& Rose, N. R. Sex differences in autoimmune disease from a pathological perspective. Am. J. Pathol. 173, 600-609 (2008)

130. Voskuhl, R. Sex differences in autoimmune diseases. Biol. Sex Differ. 2, 1 (2011).

131. Voskuhl, R. R. et al. Estriol combined with glatiramer acetate for women with relapsing-remitting multiple sclerosis: a randomised, placebo-controlled, phase 2 trial. Lancet Neurol. 15, 35-46 (2016). A clinical trial using oestrogen (specifically the placental oestrogen, oestriol) to mitigate the debilitating effects of severe multiple sclerosis, showing that oestrogens can be used therapeutically to treat immune-mediated diseases.

132. Gold, S. M., Chalifoux, S., Giesser, B. S. \& Voskuhl, R. R. Immune modulation and increased neurotrophic factor production in multiple sclerosis patients treated with testosterone. J. Neuroinflammation 5, 32 (2008)

133. Cook, M. B. et al. Sex disparities in cancer incidence by period and age. Cancer Epidemiol. Biomarkers Prev. 18, 1174-1182 (2009).

134. Cook, M. B., McGlynn, K. A., Devesa, S. S., Freedman, N. D. \& Anderson, W. F. Sex disparities in cancer mortality and survival. Cancer Epidemiol. Biomarkers Prev. 20, 1629-1637 (2011).

135. Lista, P., Straface, E., Brunelleschi, S., Franconi, F. $\&$ Malorni, W. On the role of autophagy in human diseases: a gender perspective. J. Cell. Mol. Med. 15 1443-1457 (2011)

136. Lin, P. Y. et al. B7-H1-dependent sex-related differences in tumor immunity and immunotherapy responses. J. Immunol. 185, 2747-2753 (2010).

137. Vom Steeg, L. G. \& Klein, S. L. SeXX Matters in infectious disease pathogenesis. PLoS Pathog. 12 e1005374 (2016).

A current review of sex differences in infectious diseases, with a detailed analysis of the mechanistic causes of sex differences in the outcome of infectious diseases in humans.

138. Fischer, J., Jung, N., Robinson, N. \& Lehmann, C. Sex differences in immune responses to infectious diseases. Infection 43, 399-403 (2015). 


\section{REVIEWS}

139. Sawyer, C. C. Child mortality estimation: estimating sex differences in childhood mortality since the 1970 s. PLoS Med. 9, e1001287 (2012).

This study used data from multiple sources to estimate sex ratios of mortality among children worldwide, demonstrating key differences in different regions of the world.

140. Flanagan, K. L. \& Jensen, K. J. in Sex and Gender Differences in Infection and Treatments for Infectious Diseases (eds Klein, S. L. \& Roberts, C. W.) 273-312 (Springer, 2015).

This book chapter provides a comprehensive review of sex-based differences in immunity to vaccines and infections in under-5-year-old children.

141. Griesbeck, M. \& Altfeld, M. in Sex and Gender Differences in Infection and Treatments for Infectious
Diseases (eds Klein, S. L. \& Roberts, C. W.) 103-181 (Springer, 2015)

142. Cook, I. F. Sexual dimorphism of humoral immunity with human vaccines. Vaccine 26, 3551-3555 (2008) A comprehensive review of studies demonstrating sex-based differences in antibody responses to vaccines. Multiple vaccines were implicated, highlighting the need to consider sex as a variable in vaccine immunogenicity studies.

143. Engler, R. J. et al. Half- versus full-dose trivalent inactivated influenza vaccine: age, dose, and sex effects on immune responses. Arch. Intern. Med. 168, 2405-2414 (2008).

144. Case, L. K. et al. The Y chromosome as a regulatory element shaping immune cell transcriptomes and susceptibility to autoimmune disease. Genome Res. 23, 1474-1485 (2013).
145. Fish, E. N. The X-files in immunity: sex-based differences predispose immune responses. Nat. Rev. Immunol. 8, 737-744 (2008).

146. Faisal, M., Kim, H. \& Kim, J. Sexual differences of imprinted genes' expression levels. Gene $\mathbf{5 3 3}$. 434-438 (2014)

\section{Acknowledgements}

The authors thank O. Hall and J. Peretz for assistance with tables, A. Pekosz and M. Plebanski for constructive comments on an earlier draft, and three anonymous reviewers who provided feedback that assisted with improving this Review.

Competing interests statement

The authors declare no competing interests. 